\title{
GREEN PACKAGING, GREEN PRODUCT, GREEN ADVERTISING, PERSEPSI, DAN MINAT BELI KONSUMEN
}

\author{
Imam Santoso ${ }^{1 *}$, Rengganis Fitriyani ${ }^{1}$ \\ ${ }^{1}$ Jurusan Teknologi Industri Pertanian, Fakultas Teknologi Pertanian Malang, Universitas Brawijaya \\ Malang 65145, Indonesia \\ *) E-mail: imam.santoso.ub@gmail.com
}

\begin{abstract}
Abstrak
Permasalahan lingkungan menjadi salah satu isu strategis dalam meraih daya saing global. Salah satunya adalah munculnya produk-produk yang terbuat dari bahan-bahan ramah lingkungan atau dikenal dengan istilah green product. Selanjutnya, dalam melakukan pemasaran green product, perusahaan juga menggunakan konsep green packaging dan green advertising. Penelitian ini bertujuan untuk menganalisi pengaruh green packaging, green product, dan green advertising terhadap persepsi konsumen dan minat beli produk. Penelitian dilakukan di Kelurahan Ketawanggede, Kecamatan Lowokwaru, Kota Malang. Metode pengambilan contoh menggunakan nonprobability sampling dengan teknik accidential sampling. Jumlah responden sebanyak 113 orang. Pengambilan data dilakukan dengan teknik wawancara secara langsung pada responden dengan menggunakan kuesioner. Metode analisis menggunakan Generalized Structured Component Analysis (GSCA). Hasil analisis menunjukkan bahwa green packaging, green product dan green advertising berpengaruh positif signifikan terhadap persepsi konsumen. Green product dan persepsi berpengaruh positif signifikan pada minat beli, namun green packaging dan green advertising belum terdapat bukti yang memadai dalam memengaruhi minat beli.
\end{abstract}

Kata kunci: green advertising, green packaging, green product, minat beli, persepsi konsumen

\section{Green Packaging, Green Product, Green Advertising, Consumers Perception, and Purchasing Intention}

\begin{abstract}
Environmental problems become one of the strategic issues in achieving global competitiveness. One of the issues is products that are made from environmental friendly materials or known as green product. Furthermore, in green products marketing, the company also uses green packaging and green advertising concept. This study aimed to analyze the effect of green packaging, green products, and green advertising on consumer perception and purchasing intention. The study was conducted in Ketawanggede Village, Lowokwaru Sub-district, Malang City. The sampling method used nonprobability accidential sampling techniques. The numbers of respondents were 113 consumers in study site. Data were collected by interview using questionnaires. The method of analysis used Generalized Structured Component Analysis (GSCA). The analysis showed that the green packaging, green products, and green advertising had positive significant influence on consumer perceptions. Meanwhile, green product and consumer perception had positive significant influence on purchasing interest, but the green packaging and green advertising has not found sufficient evidence in influencing purchasing intention.
\end{abstract}

Keywords: customer perception, green advertisement, green packaging, green product, purchasing intention

\section{PENDAHULUAN}

Perkembangan bisnis yang makin pesat saat ini juga diiringi dengan meningkatnya permasalahan lingkungan yang makin kompleks. Permasalahan lingkungan telah menjadi isu strategis untuk dikaji dan diselesaikan oleh berbagai pihak. Pada saat ini upaya perlindungan lingkungan semakin berkembang seiring dengan meningkatnya kesadaran konsumen. Perusahaan dan konsumen merupakan pihak yang berperan dalam menjaga kelestarian lingkungan. Dalam kondisi demikian, salah satu strategi perusahaan adalah menghasilkan berbagai macam produk yang menggunakan bahanbahan tidak merusak lingkungan atau dikenal dengan green product.

Kualitas produk merupakan aspek penting dalam memengaruhi minat beli dan kepuasan konsumen (Susila et al., 2014). Salah satu kecenderungan peningkatan kualitas produk adalah pengembangan green product. Hal ini ditujukan untuk menawarkan alternatif produk yang menggunakan bahan organik, 
menghemat penggunaan energi, menghilangkan produk beracun, dan mengurangi polusi serta limbah (Pankaj \& Vishal, 2014). Green product dirancang untuk mengurangi penggunaan sumber daya alam berlebihan pada saat proses produksi dan meminimalkan dampak lingkungan yang merugikan selama proses produksi (Albino et al., 2009; Okada \& Mais, 2010).

Salah satu permasalahan lingkungan yang utama dihadapi masyarakat saat ini adalah pencemaran sampah. Dari berbagai kasus, permasalahan sampah sangat dominan di berbagai negara terutama negara sedang berkembang. Sampah menjadi suatu permasalahan bagi lingkungan karena jumlahnya yang sangat banyak dan sulit untuk didaur ulang. Meningkatnya jumlah sampah membuat pemerintah, produsen, dan masyarakat mulai mempertimbangkan perlunya penggunaan produk yang ramah lingkungan dan dapat didaur ulang. Pada saat ini sudah waktunya untuk memperkenalkan dan menerapkan program untuk standar lingkungan dan sumber daya energi alternatif, baik sumberdaya terbarukan maupun tidak terbarukan. Pemerintah, masyarakat, dan industri mulai memiliki kesadaran untuk menerapkan pembangunan yang sadar terhadap kelestarian lingkungan.

Perlindungan terhadap lingkungan merupakan tanggung jawab yang penting yang harus diterapkan perusahaan. Perlindungan terhadap lingkungan bagi perusahaan berperan dalam meningkatkan citra positif perusahaan. Hal ini tidak hanya sebagai upaya membangun image perusahaan namun pengembangan produk yang ramah lingkungan ditujukan untuk meningkatkan pangsa pasar dan bahkan meningkatkan loyalitas konsumen. Bentuk pengembangan strategi perusahaan agar dapat bersaing secara sehat adalah menerapkan green packaging, green product, dan green advertising. Green packaging merupakan bagian dari usaha perusahaan untuk menarik minat konsumen melalui kemasan yang ramah lingkungan (Draskovic et al., 2009).

Kemasan digunakan sebagai media untuk menyampaikan atribut produk serta citra merek (Becker \& Van Rompay, 2011). Kemasan berfungsi sebagai informasi untuk meningkatkan motivasi konsumen dalam membeli produk, dan bahkan kemasan mampu memberikan kesan dan informasi mengenai produk yang memiliki kualitas tinggi (Verlegh, et al., 2005; Ruwani et al., 2014).
Green marketing merupakan strategi manajemen perusahaan dalam memasarkan produknya dengan tetap memperhatikan kelestarian lingkungan. Green advertising digunakan sebagai media untuk mempromosikan produk yang ramah lingkungan. Green advertising mencakup karakteristik dan fitur produk, proses pembuatan produk, serta kebijakan (Chen \& Chai, 2010).

Konsumen yang peduli dan memiliki pengetahuan tentang isu-isu lingkungan umumnya membeli produk yang ramah lingkungan (Laroche et al., 2001). Tingginya tingkat kekhawatiran terhadap kerusakan lingkungan serta kesadaran konsumen terhadap produk yang ramah lingkungan mendorong konsumen untuk membeli produk yang ramah lingkungan atau green product. Konsumen bahkan bersedia membayar lebih mahal untuk membeli produk yang ramah lingkungan. Hal ini karena konsumen beranggapan bahwa mengonsumsi produk ramah lingkungan dapat membantu mengurangi kerusakan lingkungan. Di lain sisi, suatu perusahaan yang sukses dengan produk yang sangat diminati konsumen, harus dapat mempertahankan keberhasilan sistem pemasarannya dan tetap mempertahankan kelestarian lingkungan (Saxena \& Khandelwal, 2012).

Pada saat ini perusahaan yang menerapkan green product semakin berkembang untuk menarik minat kosumen terhadap produk tersebut. Upaya perusahaan ini dapat memengaruhi konsumen untuk memiliki kesadaran dan membeli produk yang ramah lingkungan (Okada \& Mais, 2010; Saxena \& Khandelwal, 2012). Secara umum, kesadaran konsumen terdiri dari persepsi konsumen dan reaksi konsumen. Kesadaran konsumen bukan saja berupa pemahaman, namun juga kemauan dan kemampuan membeli dan bahkan mempromosikan produk ramah lingkungan. Kesadaran konsumen terhadap penggunaan green product selain berpengaruh terhadap minat beli (Wu \& Chen, 2014), juga dapat membantu menjaga kelestarian lingkungan (Okada \& Mais, 2010).

Studi mengenai persepsi konsumen dan minat beli terhadap produk dengan menerapkan konsep green telah dilakukan sejumlah peneliti. Patel \& Chugan (2015) menyatakan persepsi konsumen berpengaruh terhadap minat beli. Hal yang sama diungkapkan hasil riset Wu \& Chen (2014) serta Chekima \& Wafa (2015) bahwa 
kesadaran konsumen terhadap produk dan promosi berbasis green berpengaruh positif signifikan terhadap kualitas yang dirasakan dan minat beli. Hal ini mengindikasikan bahwa persepsi positif konsumen terhadap green marketing akan menjadi faktor penguat minat beli.

Berdasarkan latar belakang dan telaah riset terdahulu, tujuan penelitian ini adalah untuk menganalisis pengaruh green packaging, green product, dan green advertising terhadap persepsi dan minat beli produk. Hasil penelitian diharapkan dapat memberikan informasi ilmiah dan juga sebagai rujukan dalam mempelajari dan mengembangkan green marketing untuk meningkatkan minat beli konsumen.

\section{METODE}

Penelitian ini menggunakan metode eksplanatori untuk menganalisis hubungan green packaging, green product, dan green advertising terhadap persepsi dan minat beli. Penelitian dilakukan di Kelurahan Ketawanggede, Kecamatan Lowokwaru, Kota Malang.

Contoh adalah penduduk berusia 17 tahun ke atas dan memiliki pengalaman mengonsumsi minimal dua kali produk konsep green baik produk, kemasan, maupun media iklannya. Metode pengambilan contoh menggunakan nonprobability sampling dengan teknik accidential sampling. Jumlah contoh minimum dalam penelitian ini sebanyak jumlah parameter yang dianalisis dikali 5 sampai dengan 10 (Ghozali, 2008; Tenenhaus, 2008). Jumlah contoh yang disyaratkan minimal 75 responden (15 indikator $x$ 5). Jumlah contoh yang mengisi lengkap dan valid sebanyak 113 orang dari total 140 kuesioner yang disebar.

Data primer dalam penelitian ini meliputi karakteristik contoh (identitas, umur, pendidikan, pekerjaan), persepsi konsumen terhadap green packaging, green product, green advertising, persepsi dan minat beli (Tabel 1). Data primer dikumpulkan dengan teknik wawancara menggunakan kuesioner terhadap contoh terpilih. Pengambilan data dilakukan dengan teknik wawancara secara langsung menggunakan instrumen kuesioner. Jumlah pertanyaan sebanyak 15 buah. Kuesioner yang digunakan dalam penelitian ini merupakan kuesioner skala Likert dengan rentang penilaian 1-5 yakni: (1) sangat tidak setuju, (2) tidak setuju, (3) netral, (4) setuju dan (5) sangat setuju.

Selanjutnya, data dianalisis secara deskriptif berdasarkan kategori tertentu. Data karakteristik responden meliputi usia, jenis kelamin, pendidikan, pekerjaan serta pendapatan. Berdasarkan karakteristik usia yang digunakan adalah responden yang memiliki usia lebih dari 17 tahun. Jenis kelamin responden dikelompokan menjadi perempuan dan laki-laki.

Tabel 1. Variabel dan indikator penelitian

\begin{tabular}{|c|c|c|c|}
\hline No & Variabel & Indikator & References \\
\hline 1. & $\begin{array}{l}\text { Green } \\
\text { packaging }\end{array}$ & $\begin{array}{l}\text { - Kemasan pada green product dapat didaur ulang } \\
\text { - Kemasan pada green product dapat digunakan kembali } \\
\text { - Kemasan pada green product terbuat dari bahan daur } \\
\text { ulang } \\
\text { - Kemasan pada green product tidak menggunakan bahan } \\
\text { yang berbahaya }\end{array}$ & $\begin{array}{l}\text { Rokka \&Uusitalo (2008); } \\
\text { Rundh (2009); } \\
\text { Draskovic et al. (2009) }\end{array}$ \\
\hline 2. & $\begin{array}{l}\text { Green } \\
\text { product }\end{array}$ & $\begin{array}{l}\text { - Green product bermanfaat bagi lingkungan } \\
\text { - Kinerja green product sesuai harapan saya } \\
\text { - Bahan baku green product terbuat dari bahan-bahan yang } \\
\text { tidak berbahaya }\end{array}$ & $\begin{array}{l}\text { Pankaj \& Vishal (2014); } \\
\text { Kong et al. (2015) }\end{array}$ \\
\hline 3. & $\begin{array}{l}\text { Green } \\
\text { advertising }\end{array}$ & $\begin{array}{l}\text { - Informasi pada eco-label mudah dimengerti } \\
\text { - Tampilan pada eco-label akurat }\end{array}$ & $\begin{array}{l}\text { Patel \& Chugan (2015; } \\
\text { Wu \& Chen (2014) }\end{array}$ \\
\hline 4. & $\begin{array}{l}\text { Persepsi } \\
\text { konsumen }\end{array}$ & $\begin{array}{l}\text { - Persepsi menggunakan green product dapat berkontribusi } \\
\text { untuk mengurangi pencemaran lingkungan } \\
\text { - Persepsi mengonsumsi green product lebih menyehatkan } \\
\text { dan aman dibanding dengan produk lainnya } \\
\text { - Persepsi green product memiliki jaminan kualitas yang } \\
\text { baik }\end{array}$ & $\begin{array}{l}\text { Patel \& Chugan (2015); } \\
\text { Kong et al. (2015) }\end{array}$ \\
\hline 5. & Minat beli & $\begin{array}{l}\text { - Minat beli green product karena bermanfaat bagi } \\
\text { lingkungan } \\
\text { - Minat beli green product karena tidak menimbulkan } \\
\text { pencemaran lingkungan } \\
\text { - Minat membeli green product karena memiliki perhatian } \\
\text { yang lebih pada lingkungan dibandingkan produk lain }\end{array}$ & $\begin{array}{l}\text { Wu \& Chen (2014); } \\
\text { Chekima \& Wafa (2015); } \\
\text { Barnes et al. (2011) }\end{array}$ \\
\hline
\end{tabular}


Selanjutnya tingkat pendidikan dikelompokkan menjadi SMP, SMA, Diploma dan Sarjana serta lainnya. Berdasarkan jenis pekerjaan dibagi menjadi tidak bekerja, pelajar atau mahasiswa, ibu rumah tangga, wiraswasta, pegawai swasta, dokter/ paramedis, pegawai negeri dan lainnya. Pendapatan dikelompokkan menjadi (1) <Rp2.000.000, (2) Rp2.000.000-Rp3.000.000, (3) Rp3.001.000Rp4.000.000, (4) Rp4.001.000-Rp5.000.000, dan (5) >Rp5.000.000. Model struktural variabel penelitian ini dapat dilihat pada Gambar 1.

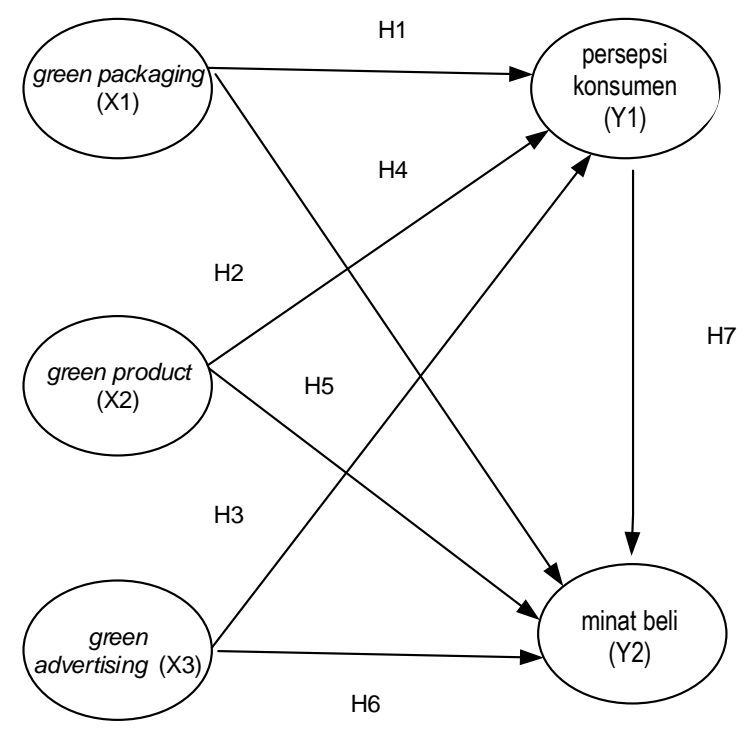

Gambar 1 Model struktural variabel penelitian

Hipotesis dalam penelitian ini terdiri atas:

$\mathrm{H}_{1}$ : Green packaging berpengaruh signifikan pada persepsi konsumen

$\mathrm{H}_{2}$ : Green product berpengaruh signifikan pada persepsi konsumen

$\mathrm{H}_{3}$ : Green advertisement berpengaruh signifikan pada persepsi konsumen

$\mathrm{H}_{4}$ : Green packaging berpengaruh signifikan pada minat beli

$\mathrm{H}_{5}$ : Green product berpengaruh signifikan pada minat beli

$\mathrm{H}_{6}$ : Green advertisement berpengaruh signifikan pada minat beli

$\mathrm{H}_{7}$ : Persepsi konsumen berpengaruh signifikan pada minat beli.

\section{HASIL}

\section{Karakteristik Responden}

Karakteristik responden pada penelitian meliputi usia, jenis kelamin, pendidikan, pekerjaan, dan penghasilan. Hasil karakteristik responden pada penelitian ini dapat dilihat pada Tabel 2. Berdasarkan hasil penelitian, responden terbanyak berusia 1725 tahun $(77,8 \%)$, sedangkan pada usia 26 55 tahun sebanyak 22,2 persen. Penelitian ini menunjukkan bahwa sebagian besar konsumen adalah perempuan sebanyak 62,8 persen dan sebanyak 37,2 persen berjenis kelamin laki-laki. Jika dilihat dari tingkat pendidikan, sebagian besar responden berpendidikan sarjana yakni sebanyak 57,5 persen, responden dengan tingkat pendidikan SMA sebanyak 40,7 persen Hasil penelitian ini menunjukkan tidak ada responden yang berpendidikan SD dan hanya sebanyak 0,9 persen berpendidikan SMP.

Berdasarkan klasifikasi pekerjaan dapat diketahui bahwa responden dengan pekerjaan sebagai pelajar dan mahasiswa sebanyak 36,3 persen, pegawai swasta sebanyak 38,9 persen, pegawai negeri sebanyak 11,5 persen, ibu rumah tangga sebanyak 4,4 persen serta responden dengan pekerjaan lainnya sebanyak 8,8 persen. Berdasarkan tingkat pendapatan per bulan, responden berpenghasilan lebih dari Rp2.000.000 sebanyak 53,1 persen, berpenghasilan antara Rp2.000.000 hingga Rp3.000.000 sebanyak 15,0 persen. Responden dengan penghasilan antara Rp3.001.000 hingga Rp4.000.000 sebanyak 16,8 persen, berpenghasilan antara Rp4.001.000 hingga 5.000.000 sebanyak 6,2 persen. Sementara itu, responden yang memiliki penghasilan lebih dari Rp5.000.000 sebanyak 8,8 persen.

Tabel 2 Sebaran karakteristik responden

\begin{tabular}{|c|c|c|c|}
\hline Karakteristik & $\begin{array}{l}\text { Gambaran } \\
\text { Responden }\end{array}$ & $\mathrm{n}$ & $\%$ \\
\hline $\begin{array}{l}\text { Usia } \\
\text { (tahun) }\end{array}$ & $\begin{array}{l}17-25 \\
26-55\end{array}$ & $\begin{array}{l}88 \\
25\end{array}$ & $\begin{array}{l}77,8 \\
22,2\end{array}$ \\
\hline Jenis & Laki-laki & 42 & 37,2 \\
\hline Kelamin & Perempuan & 71 & 62,8 \\
\hline \multirow[t]{4}{*}{ Pendidikan } & SMP & 1 & 0,9 \\
\hline & SMA & 46 & 40,7 \\
\hline & $\begin{array}{l}\text { Perguruan } \\
\text { tinggi }\end{array}$ & 65 & 57,5 \\
\hline & Lainnya & 1 & 0,9 \\
\hline \multirow[t]{5}{*}{ Pekerjaan } & Mahasiswa & 41 & 36,3 \\
\hline & $\begin{array}{l}\text { Pegawai } \\
\text { Swasta }\end{array}$ & 44 & 38,9 \\
\hline & Pegawai Negeri & 13 & 11,5 \\
\hline & $\begin{array}{l}\text { Ibu rumah } \\
\text { tanqga }\end{array}$ & 5 & 4,4 \\
\hline & Lainnya & 10 & 0,9 \\
\hline \multirow[t]{5}{*}{ Penghasilan } & $<$ Rp2.000.000 & 60 & 53,1 \\
\hline & $\begin{array}{l}\text { Rp2.000.000- } \\
\text { Rp3.000.000 }\end{array}$ & 17 & 15,0 \\
\hline & $\begin{array}{l}\text { Rp3.001.000- } \\
\text { Rp4.000.000 }\end{array}$ & 19 & 16,8 \\
\hline & $\begin{array}{l}\text { Rp4.001.000- } \\
\text { Rp5.000.000 }\end{array}$ & 7 & 6,2 \\
\hline & $>$ Rp5.000.000 & 10 & 8,8 \\
\hline
\end{tabular}




\section{Green Packaging}

Green packaging merupakan variabel yang diduga berpengaruh terhadap persepsi dan minat beli konsumen. Hasil penelitian menunjukkan bahwa secara keseluruhan variabel green packaging mendapat tanggapan positif dari konsumen. Berdasarkan hasil analisis, indikator yang memperoleh jawaban setuju dan sangat setuju paling banyak adalah green product dapat digunakan kembali $(81,3 \%)$ dan hanya 0,9 persen menyatakan tidak setuju dan sangat tidak setuju. Indikator yang sebagian besar jawaban konsumen menyatakan netral $(42,4 \%)$ adalah kemasan pada green product dapat didaur ulang. Sementara itu, sebagian besar responden menyatakan setuju dan sangat setuju terhadap kedua indikator lainnya.

Hasil juga menunjukkan bahwa sebanyak 74,1 persen menyatakan setuju dan sangat setuju untuk indikator green product yang terbuat dari bahan-bahan daur ulang dan sebanyak 59,8 persen untuk indikator proses produksi green product tidak menggunakan bahan-bahan yang berbahaya bagi lingkungan dan kesehatan konsumen. Hasil penelitian menunjukkan bahwa mayoritas konsumen sudah mengerti dan memahami pentingnya penerapan green packaging. Hal ini karena adanya kesadaran konsumen untuk tetap menjaga dan memperhatikan kelestarian lingkungan. Penggunaan green packaging dianggap oleh konsumen dapat membantu berkontribusi untuk mengurangi jumlah sampah yang tidak dapat didaur ulang.

\section{Green Product}

Green product merupakan faktor yang dinilai berpengaruh terhadap persepsi dan motivasi konsumen dalam memilih produk serta menjadi isu yang menarik dalam mengatasi permasalahan Indikator green product terdiri dari tiga indikator yang masing-masing memiliki pengaruh yang berbeda. Indikator yang memperoleh jawaban setuju dan sangat setuju paling banyak $(64,3 \%)$ adalah indikator kinerja green product sesuai harapan dan hanya 7,1 persen menyatakan tidak setuju. Indikator yang jawaban tidak setuju dan sangat tidak setuju paling kecil $(3,6 \%)$ adalah green product bermanfaat bagi lingkungan. Pendapat responden yang jawaban tidak setuju dan sangat tidak setuju paling tinggi $(27,7 \%)$ adalah indikator bahan baku green product terbuat dari bahan-bahan yang tidak berbahaya.

\section{Green Advertising}

Sebanyak 44,6 persen responden menyatakan setuju apabila informasi pada eco-label mudah dimengerti, dan sebanyak 40,2 persen konsumen menyatakan sangat setuju apabila apa yang ditampilkan pada eco-label akurat. Tanggapan responden terhadap penerapan green advertising pada produk sudah baik. Hal ini terlihat dari sebanyak 50,0 persen responden menyatakan bahwa penerapan eco-label pada produk dapat membantu menarik minat konsumen untuk membeli produk tersebut.

\section{Persepsi Konsumen}

Indikator green product dapat berkontribusi untuk mengurangi pencemaran lingkungan memperoleh proporsi jawaban setuju paling banyak yakni 41,1 persen dan hanya 8,9 persen konsumen yang menyatakan tidak setuju. Indikator mengonsumsi green product lebih menyehatkan dan aman jika dibandingkan dengan produk lainnya memperoleh proporsi jawaban setuju paling banyak yakni 44,6 persen. Indikator green product memiliki jaminan kualitas dan mutu yang baik, ditemukan memperoleh proporsi jawaban setuju sebesar 42,9 persen. Hasil analisis menunjukkan responden memperhatikan pentingnya penerapan green packaging, green product dan green advertising pada suatu produk yang dijual. Konsumen beranggapan menggunakan produk yang ramah lingkungan dapat meningkatkan persepsi positif. Hal ini karena selain persepsi produk berkualitas lebih baik, sehat dan aman, juga dinilai berkontribusi mengurangi jumlah sampah atau limbah yang tidak dapat didaur ulang.

\section{Minat Beli}

Indikator minat membeli green product karena bermanfaat bagi lingkungan memperoleh proporsi jawaban setuju dan sangat setuju sebanyak 47,3 persen sedangkan yang sangat tidak setuju dan setuju hanya $15,2 \%$. Jawaban setuju dan sangat setuju untuk indikator minat membeli green product karena tidak menimbulkan pencemaran lingkungan sebesar 50,0 persen dan jawaban tidak setuju dan sangat tidak setuju sebesar 22,3 persen. Indikator minat membeli green product karena memiliki perhatian yang lebih pada lingkungan dibandingkan produk lain diapresiasi paling tinggi yakni setuju dan sangat setuju sebesar 62,5 persen sedangkan yang tidak setuju dan sangat tidak setuju sebesar 14,3 persen. 


\section{Uji Instrumen Penelitian}

Metode penelitian ini menggunakan analisis multivariat GSCA (Generalized Structured Component Analysis). Nilai r-hitung > r-tabel pada $\alpha=0,1$ dan nilai Cronbach's alpha pada penelitian sebesar $0,865(>0,6)$. Hal ini menunjukkan bahwa semua indikator dan variabel yang digunakan bersifat valid dan reliabel. Berdasarkan hasil uji pada nilai sig linieritas diketahui bahwa semua variabel $X$ telah linier terhadap variabel $Y$. Hasil analisis menunjukkan bahwa model yang terbentuk pada penelitian ini dapat menjelaskan semua variabel sebesar 0,489.

Keragaman variabel green packaging, green product, green advertising, dan persepsi konsumen dapat dijelaskan oleh model sebesar 48,9 persen dan sisanya 47,7 persen dapat dijelaskan oleh variabel lain. Hasil pengujian hipotesis pada penelitian ini dilihat pada nilai path coefficients pada structural model. Pengujian hipotesis yang dilakukan didasarkan pada measures of fit pada model struktural, yakni berdasarkan nilai signifikansi pada estimasi parameternya dilihat dari nilai critical ratio (Hwang \& Takane, 2010). Hasil analisis GSCA digunakan untuk merumuskan model matematis. Model matematis dari penelitian ini ditunjukkan dengan nilai estimate di path coefficients. Persamaannya adalah:

$Y_{1}=0,389 X_{1}+0,338 X_{2}+0,17 X_{3} ;$ dan

$Y_{2}=0,152 x_{1}+0,312 x_{2}+0,050 \times 3+0,349 Y_{1}$

Keterangan: $X_{1}$ (green packaging), $X_{2}$ (green product), $X_{3}$ (green advertising), $Y_{1}$ (persepsi konsumen) dan $Y_{2}$ (minat beli).

\section{Uji Hipotesis}

Hasil analisis pada penelitian ini dapat dilihat pada Tabel 3. Hasil estimasi loading factor model struktural disajikan pada Gambar 2. Hasil analisis menunjukkan bahwa semua variabel pada penelitian ini berpengaruh positif dan signifikan. Pengujian hipotesis dapat dilihat pada tabel measures of fit structural model. Pengujian hipotesis dilakukan dengan membandingkan nilai $\mathrm{CR}$ dengan nilai pada t-tabel $(1,96)$. Hasil analisis menunjukkan bahwa green packaging berpengaruh signifikan pada persepsi konsumen, green product berpengaruh signifikan pada persepsi konsumen, green advertising berpengaruh signifikan pada persepsi konsumen, dan persepsi konsumen berpengaruh signifikan pada minat beli.
Tabel 3 Measures of fit structural model

\begin{tabular}{lllll}
\hline \multicolumn{1}{c}{ Path } & Estimate & SE & CR & Keterangan \\
\hline $\begin{array}{l}\text { Green packaging } \\
\rightarrow \text { persepsi } \\
\text { konsumen }\end{array}$ & 0,389 & 0,141 & $2,75^{*}$ & Signifikan \\
$\begin{array}{l}\text { Green product } \rightarrow \\
\text { Persepsi }\end{array}$ & 0,338 & 0,138 & $2,44^{*}$ & Signifikan \\
$\begin{array}{l}\text { Konsumen } \\
\text { Green advertising } \\
\rightarrow \text { Persepsi }\end{array}$ & 0,179 & 0,069 & $2,6^{*}$ & Signifikan \\
$\begin{array}{l}\text { Konsumen } \\
\text { Green packaging } \\
\rightarrow \text { Minat beli }\end{array}$ & 0,152 & 0,133 & 1,14 & $\begin{array}{c}\text { Tidak } \\
\text { signifikan }\end{array}$ \\
$\begin{array}{l}\text { Green product } \rightarrow \\
\text { Minat beli } \\
\text { Green advertising } \\
\rightarrow \text { Minat beli }\end{array}$ & 0,312 & 0,133 & $2,35^{*}$ & $\begin{array}{c}\text { Signifikan } \\
\text { Tidak }\end{array}$ \\
$\begin{array}{l}\text { Persepsi } \\
\text { konsumen } \rightarrow\end{array}$ & 0,050 & 0,091 & 0,55 & $\begin{array}{c}\text { Signifikan } \\
\text { Minat beli }\end{array}$ \\
\hline
\end{tabular}

\section{PEMBAHASAN}

Permasalahan lingkungan menjadi bagian yang paling penting ditangani baik oleh perusahaan, masyarakat maupun pemerintah. Perusahaan memegang peran penting dalam mengatasi permasalahan lingkungan. Bentuk upaya yang dilakukan perusahaan dalam membantu mengatasi permasalahan lingkungan adalah dengan menciptakan produk yang ramah lingkungan. Pada saat ini produk yang ramah lingkungan mempunyai daya tarik tersendiri bagi konsumen. Perubahan gaya hidup yang mulai sadar akan pentingnya menjaga kelestarian lingkungan membuat konsumen mulai beralih dari produk biasa ke produk yang ramah lingkungan. Tingkat permintaan konsumsi green product dipengaruhi oleh beberapa faktor yaitu green packaging, green product value dan green advertising.

Berdasarkan hasil penelitian diketahui bahwa green packaging berpengaruh positif dan signifikan terhadap persepsi konsumen. Sejalan dengan penelitian yang dilakukan oleh Barber (2010), yang menyatakan green packaging memengaruhi persepsi konsumen dalam melakukan pembelian suatu produk. Konsumen mempertimbangkan manfaat dan dampak yang ditimbulkan dari kemasan suatu produk terhadap kelestarian lingkungan. Saat ini, tingkat kesadaran konsumen terhadap kelestarian lingkungan semakin menguat seiring dengan meningkatnya pengetahuan dan berbagai informasi yang dipublikasikan. Saat ini terdapat kecenderungan konsumen menginginkan produk dengan kemasan yang ramah lingkungan dan dapat didaur ulang. Pola pikir masyarakat pada saat ini sudah mulai bergeser ke arah perlindungan dan kelestarian lingkungan. 


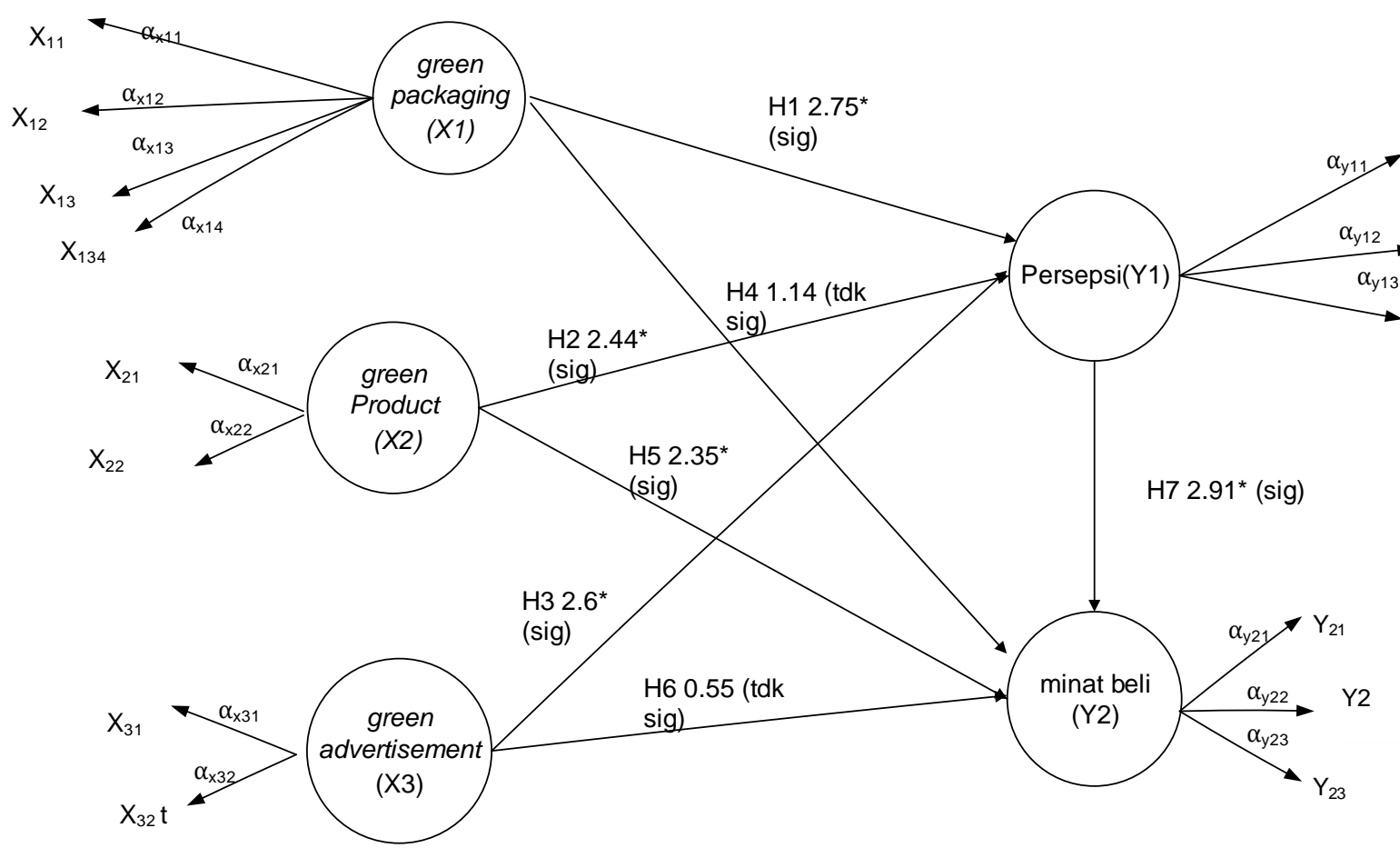

Gambar 2 Hasil estimasi loading factor model struktural

Kemasan dengan konsep green packaging menawarkan konsep yang berbeda dibandingkan dengan produk pada umumnya. Green packaging menggunakan kemasan yang dapat didaur ulang dan dapat digunakan kembali. Selain itu, green packaging juga menggunakan bahan baku yang berkualitas dan tahan lama. Green packaging yang berbahan baku plastik, terbuat dari bahan plastik yang memiliki kualitas tinggi dan aman untuk kesehatan. Kemasan plastik pada green packaging memiliki bentuk yang relatif sederhana, dengan demikian tidak menimbulkan sampah yang sulit didaur ulang. Selain itu, green packaging yang terbuat dari plastik dapat digunakan kembali oleh konsumen sebagai media tanam untuk tanaman hias maupun digunakan kembali untuk kebutuhan lainnya. Bahan baku green packaging dapat juga terbuat dari kertas yang mudah untuk didaur ulang. Hal ini dikarenakan kemasan kertas tidak dapat digunakan kembali untuk kebutuhan yang sama jika sudah digunakan.

Konsumen memiliki persepsi bahwa kemasan yang terbuat dari bahan baku biodegradable lebih baik. Hal ini karena kemasan tersebut dianggap tidak menghasilkan sampah yang berlebih dan mencemari lingkungan. Hasil penelitian ini diperkuat temuan riset yang dilakukan oleh Barnes et al. (2011), bahwa sebanyak 66,5 persen responden yang ada di USA memiliki persepsi kemasan yang terbuat dari bahan biodegradable lebih baik dan lebih bermanfaat.

Sebagian besar responden pada penelitian ini sudah memiliki kesadaran yang tinggi terhadap kelestarian lingkungan. Konsumen beranggapan bahwa produk yang memiliki kemasan yang ramah lingkungan bermanfaat agar tidak menambah volume sampah yang sudah ada. Konsumen memiliki persepsi yang lebih baik pada pada kemasan yang dapat didaur ulang, tidak menggunakan bahan berbahaya bagi lingkungan serta yang dapat digunakan kembali. Hasil penelitian ini juga sejalan dengan penelitian Rokka \& Uusitalo (2008), yang menyatakan bahwa sebagian besar konsumen di Finlandia beranggapan bahwa green packaging selain menyajikan informasi yang lengkap, didesain menarik dan dapat didaur ulang.

Hasil penelitian menemukan bahwa nilai jalur green product berpengaruh positif signifikan terhadap persepsi konsumen. Temuan riset ini sejalan dengan hasil penelitian Kong et al. (2014) bahwa green product berpengaruh signifikan terhadap persepsi konsumen. Hasil riset ini mengungkapkan green product yang meliputi indikator manfaat bagi lingkungan, kinerja produk sesuai harapan dan bahan baku produk terbuat dari bahan yang tidak berbahaya berperan penting dalam membentuk persepsi konsumen. Green product dipersepsikan konsumen sebagai 
produk yang memiliki kualitas produk yang lebih tinggi jika dibandingkan dengan produk umumnya. Green product umumnya menggunakan bahan baku pilihan yang memiliki kualitas dan manfaat yang baik untuk kesehatan konsumen dan untuk kelestarian lingkungan. Konsumen beranggapan bahwa mengonsumsi green product memberikan rasa lebih aman dan dinilai lebih sehat. Penggunaan bahan baku yang berkualitas dan sesuai standar memberikan jaminan kualitas produk yang baik bagi konsumen. Menurut Eskildsen et al. (2004), menyatakan bahwa kualitas green product memiliki dampak secara langsung pada kinerja dan memiliki hubungan yang erat dengan persepsi maupun minat beli konsumen. Hal ini juga diperkuat pendapat Chumpitaz \& Paparoidamis (2004), bahwa green product yang berkualitas baik akan memberikan kepuasan pada pelanggan.

Green product memiliki banyak manfaat bagi lingkungan antara lain dapat mengurangi pencemaran dan polusi udara yang dihasilkan dari proses produksi. Kemasan pada green product yang ramah lingkungan dan dapat didaur ulang dapat mengurangi jumlah sampah yang ada di sekitar kita. Selain itu, green product juga dapat menghemat energi pada saat proses produksi berlangsung. Konsumen beranggapan bahwa mengonsumsi atau menggunakan green product dapat secara langsung turut serta berkontribusi untuk mengurangi jumlah pencemaran lingkungan. Green product dapat menghemat energi dan dapat mengurangi atau menghilangkan penggunaan agen beracun, polusi, dan limbah (Pankaj \& Vishal, 2014). Meskipun demikian, konsumen memerlukan biaya yang tinggi untuk mengonsumsi atau menggunakan green product (Chen \& Chai, 2010) dibandingkan dengan produk biasa.

Hasil penelitian ini juga menunjukkan bahwa green advertising berpengaruh positif dan signifikan terhadap persepsi konsumen. Temuan riset ini mengindikasikan green advertising yang meliputi indikator informasi eco-label mudah dimengerti dan hal yang disajikan dalam eco-label bernilai akurat dapat memengaruhi persepsi konsumen. Hasil penelitian ini sejalan dengan penelitian yang dilakukan Patel \& Chuqan (2015) bahwa green advertising secara signifikan berpengaruh terhadap persepsi konsumen tentang perusahaan yang peduli terhadap lingkungan. Konsumen beranggapan bahwa perusahaan yang menerapkan green advertising dinilai turut serta dalam menjaga kelestarian lingkungan.

Green advertising pada perusahaan memiliki peran yang penting, yakni sebagai pencitraan terhadap produk dalam meningkatkan persepsi konsumen. Menurut Rahim (2012), green advertising adalah suatu iklan yang bertujuan untuk mempromosikan produk maupun jasa, ide atau kemampuan perusahaan dalam mengurangi kerusakan dan pencemaran lingkungan. Green advertising berfungsi untuk memberikan pencitraan khusus bagi perusahaan mengenai green product yang bertujuan peduli terhadap lingkungan. Perusahaan melalui green advertising mengenalkan citra kepada masyarakat tentang green product yang dipasarkan sehingga konsumen dapat mengenal green product secara lebih dalam.

Pada perusahaan, penerapan green advertising diwujudkan dalam eco-labeling. Rex \& Bauman (2007) menilai eco-label sebagai alat untuk membantu pengambil motivasi untuk membeli green product serta memberikan informasi tentang produk. Pada saat ini, konsumen beranggapan dengan membeli produk yang memiliki eco-label berarti turut berkontribusi dalam menjaga Ingkungan. Perusahaan yang memiliki ecolabel dapat meningkatkan pangsa pasar dari green product. Citra eco-labeling pada perusahaan bertujuan sebagai strategi yang dilakukan oleh perusahaan untuk memberikan citra bahwa perusahaan tersebut tidak semata-mata melihat dari segi keuntungan, namun lebih memperhatikan pada aspek lingkungan. Menurut Chen (2008), citra perusahaan yang menerapkan green advertising akan meningkatkan persepsi konsumen terkait dengan kelestarian lingkungan.

Menurut Orth, Campana dan Malkewitz (2010), kemasan merupakan bagian integral dan mengambarkan citra merek pada suatu produk yang dirancang untuk menyampaikan informasi yang pada produk. Hasil analisis menunjukkan bahwa belum terdapat bukti yang memadai adanya pengaruh signifikan green packaging terhadap minat beli konsumen. Hasil penelitian ini tidak sejalan dengan temuan Barber (2010), yang menyatakan bahwa green packaging berpengaruh langsung terhadap minat beli suatu produk. Saat ini, konsumen dihadapkan dengan banyak pilihan terhadap produk. Salah satunya, adanya kesamaan kemasan yang digunakan pada produk sejenis. Padahal 
bahan kemasan dan kualitas produk tersebut berbeda. Akibatnya adalah konsumen mengalami kesulitan dalam membedakan kemasan produk satu dengan produk yang lainnya. Konsumen masih belum bisa membedakan dengan cepat mana produk yang menggunakan kemasan ramah lingkungan dengan produk yang menggunakan kemasan biasa.

Salah satu strategi yang dapat diterapkan oleh perusahaan untuk menarik konsumen melakukan pembelian adalah membuat kemasan yang menarik, memiliki label, desain dan bentuk yang unik dan berbeda dengan produk pada umumnya. Perusahaan dapat menerapkan dan menampilkan eco-label pada produk, sehingga konsumen dapat membedakan mana produk yang memiliki kemasan yang ramah lingkungan dan tidak. Selain itu, perusahaan juga dapat menerapkan dan meningkatkan pemasaran terhadap produknya melalui berbagai iklan yang menawarkan konsep green product. Kelengkapan informasi yang terdapat pada produk berperan dalam memengaruhi minat beli konsumen. Menurut Rundh (2009), kemasan pada produk dapat menggantikan peran dari tenaga penjual dalam memberikan informasi yang memadai. Konsumen dapat menunda melakukan minat beli akibat kurangnya informasi yang memadai dan lengkap pada kemasan suatu produk.

Hasil penelitian lain menunjukkan bahwa green product berpengaruh positif dan signifikan terhadap minat beli. Hal ini mengindikasikan bahwa semakin tinggi nilai green product akan meningkatkan minat beli konsumen. Hal ini berarti indikator produk bermanfaat bagi lingkungan, kinerja green product sesuai harapan dan bahan baku tidak mengandung hal-hal yang berbahaya berperan signifikan memengaruhi minat beli konsumen. Hasil penelitian ini sejalan dengan temuan riset yang dilakukan D'Souza et al. (2006) bahwa perusahaan yang mengembangkan green product dapat menarik konsumen untuk membeli produk tersebut. Perusahaan beranggapan dengan menerapkan green product konsumen akan lebih tertarik dan termotivasi serta meningkatkan minat pembelian terhadap produk yang dinilai lebih memiliki kepedulian terhadap lingkungan.

Menurut Dangelico \& Pontrandolfo (2010), pada saat ini permintaan terhadap green product meningkat secara signifikan. Fenomena isu pemanasan global dan maraknya jumlah sampah yang ada di lingkungan merupakan faktor yang berpengaruh terhadap konsumen sehingga lebih sadar akan pentingnya menjaga lingkungan. Konsumen mulai menerapkan untuk berperilaku hijau dalam melakukan pembelian terhadap produk.

Hasil penelitian lainnya menunjukkan bahwa belum terdapat bukti memadai adanya pengaruh positif yang signifikan dari green advertising terhadap minat beli. Hasil penelitian ini sejalan dengan penelitian yang dilakukan oleh Bhaskaran et al. (2006), yang menyatakan bahwa konsumen tidak melihat produk tersebut berdasarkan iklan yang menawarkan kelestarian lingkungan. Konsumen juga belum sepenuhnya percaya terhadap perusahaan yang menjadikan green advertising sebagai media untuk memasarkan produknya. Sebagian besar konsumen justru lebih tertarik dengan manfaat dari produk yang ditawarkan.

Selanjutnya, minat beli konsumen tidak terlalu memperhatikan eco-branding dan eco-label pada produk. Eco-branding dan eco-label pada produk belum mampu untuk meningkatkan citra pada produk. Pada umumnya minat beli konsumen terhadap suatu produk dikarenakan adanya kebutuhan dan ketersediaan produk tersebut di sekitar konsumen. Konsumen akan membeli produk jika membutuhkannya dan produk tersebut sesuai dengan persepsinya. Pada beberapa kasus, konsumen juga kurang memperhatikan secara rinci label yang terdapat pada produk. Hal ini dikarenakan dalam melakukan minat beli dilakukan dalam waktu yang sangat singkat.

Upaya perusahaan dalam meningkatkan peran green advertising agar diterima konsumen dapat dilakukan dengan lebih gencar dalam mempromosikan produknya. Strategi perusahaan untuk meningkatkan green advertising dapat dilakukan dengan membuat iklan yang berkonsep tentang kepedulian terhadap lingkungan, sebagai contoh perusahaan dapat mencantumkan bentuk gambar pemandangan alam dan mencantumkan produk yang ramah lingkungan. Perusahaan juga dapat membuat slogan untuk mengajak konsumen agar lebih peduli terhadap lingkungan dan membeli green product.

Hasil penelitian lain menunjukkan bahwa nilai jalur green packaging berpengaruh positif dan signifikan terhadap persepsi konsumen. 
Tingginya kesadaran konsumen akan pentingnya menjaga dan melestarikan lingkungan menjadi faktor yang sangat berpengaruh terhadap minat beli konsumen. Pada saat ini, konsumen cenderung lebih memperhatikan faktor lingkungan ketika memutuskan untuk membeli atau mengunakan suatu produk. Konsumen beranggapan dengan menggunakan dan mengonsumsi green product berarti turut serta berkontribusi dalam menjaga dan melestarikan lingkungan. Laroche et al., (2001) menyatakan bahwa konsumen yang peduli dan memiliki pengetahuan tentang isuisu lingkungan, pada saat berbelanja atau mengunakan suatu produk akan membeli produk yang ramah lingkungan.

Menurut Schiffman \& Kanuk (2004) dan Chekima \& Wafa (2015), minat beli pada suatu produk dipengaruhi oleh perilaku konsumen yang mencakup psikologi, sosiologi, antropologi, sejarah dan ekonomi. Tingkat ekonomi dari konsumen berpengaruh signifikan dalam menentukan produk yang dikonsumsi. Sebelum konsumen melakukan minat beli terhadap suatu produk, konsumen akan terlebih dahulu mencari informasiinformasi sebanyak mungkin terkait produk tersebut. Oleh karena itu, perusahaan yang menerapkan green product hendaknya memberikan informasi yang jelas dan lengkap terkait produk yang dipasarkan agar konsumen dapat dengan mudah untuk mendapatkan informasi tentang produk tersebut. Selain itu, minat beli konsumen terhadap green product juga didasarkan pada manfaat dari green product. Konsumen beranggapan bahwa mengonsumsi green product akan lebih aman jika dibandingkan dengan produk lainnya. Namun D'Souza et al. (2006) menyatakan bahwa green product pada umumnya memiliki harga yang lebih mahal jika dibandingkan dengan produk pada umumnya sehingga perlu diperhatikan sasaran dari green product.

\section{SIMPULAN DAN SARAN}

Hasil penelitian menunjukkan bahwa green packaging berpengaruh signifikan terhadap persepsi konsumen. Hal ini karena konsumen cenderung menginginkan produk dengan kemasan yang ramah lingkungan dan dapat didaur ulang. Green product berpengaruh signifikan pada persepsi konsumen Konsumen beranggapan bahwa green product memiliki kualitas yang lebih tinggi jika dibandingkan dengan produk pada umumnya. Green advertising berpengaruh signifikan terhadap persepsi konsumen. Green advertising berperan dalam memberikan pencitraan lebih baik sebagai produsen peduli terhadap lingkungan. Green packaging dan green advertising belum cukup bukti secara langsung memengaruhi minat beli. Sementara itu, green product berpengaruh signifikan pada minat beli.

Bagi konsumen, green product menjadi salah satu solusi dalam menjaga lingkungan. Namun dengan adanya persaingan perusahaan untuk menarik minat beli, konsumen harus lebih bijak dan cerdas saat memilih produk. Salah satu caranya adalah dengan mencari informasi terkait green product yang akan dibeli. Informasi yang didapat konsumen tidak hanya berasal dari iklan yang diberikan perusahaan, namun juga berasal dari berbagai sumber. Upaya ini akan membantu konsumen untuk mendapatkan produk yang sesuai dengan harapan.

Selanjutnya perlu dilakukan penelitian lanjutan untuk menganalisis variabel lain yang berpengaruh terhadap minat beli produk dengan green marketing seperti peran pengetahuan, ketersediaan produk dan keterjangkauan harga, dan sebagainya. Penelaahan lebih mendalam dapat difokuskan pada ketersediaan green product secara spesifik di pasaran dan tingkat persepsi konsumen. Kajian lain yang dapat dilakukan yaitu analisis strategi pengembangan green marketing yang tidak saja meningkatkan minat beli konsumen, namun juga dapat mengedukasi pengetahuan konsumen.

\section{DAFTAR PUSTAKA}

Albino, V., Balice, A., Dangelico, R.M. (2009). Environmental strategies and green product development: an overview on sustainability-driven companies. Business Strategy and the Environment, 8(2), 83-96.

Barber, N. (2010). Greenwine packaging: Targeting environmental consumers. International Journal of Wine Business Research, 22 (4), 423-444.

Barnes, M., Chan-Halbrendt, C., Zhang, Q.G. \& Abejon, N. (2011). Consumer preference and willingness to pay for non-plastic food containers in Honolulu, USA. Journal of Environmental Protection. 2 (9), 1264-1273.

Becker, L., \& Van Rompay, T. L. (2011). Tough package, strong taste: The 
influence of packaging design on taste impressions and product evaluations. Food Quality \& Preference, 22 (1), 1723.

Bhaskaran, S., Polonsky, M., Cary, J. \& Fernandez, S. (2006). Environmentally sustainable food production and marketing - opportunity or hype? British Food Journal. 108 (8), 677-690.

Chan, R.Y.K. (2004). Consumer responses to environmental advertising in China. Marketing Intelligence \& Planning, 22. (4), 427-437.

Chekima, B. \& Wafa, S.A.W.S.K. (2015). Determinant factors of consumers' green purchase intention: The moderating role of environmental advertising. Asian Social Science, 11(10):318-329. doi:10.5539/ass.v11n10p318.

Chen, Y.S. (2008). The driver of green innovation and green image -green Core competence. Journal Business Ethics. 81 (3), 531-543.

Chen, T.B., \& Chai, L.T. (2010). Attitde towards environment and green products: Consumers perspective. Management Science and Engineering, 4 (2), 27-39.

Chumpitaz R. \& Paparoidamis, N.G. (2004). Service quality and marketing performance in business-to-business markets: exploring the mediating role of client satisfaction. Managing Service. Quality. 14 (2), 235-248.

D'Souza, C., Taghian, M., Lamb, P. \& Peretiatkos, R. (2006). Green products and corporate strategy: An empirical investigation. Society and Business Review, 1(2). 144-157.

Dangelico, R.M. \& Pontrandolfo, P. (2010). From green product definitions and classifications to the green option matrix. Journal of Cleaner Production. 18 (6), 1608-1628.

Draskovic, N., Temperly, J. \& Pavicic, J. (2009). Comparative perception(S) of consumer goods packaging: Croatian consumers' perspective(S). International Journal of Management Cases, 11 (2), 154-163.

Eskildsen J.K., Kristensen K., Juhl H.J. \& Ostergaard P. (2004). The drivers of customer satisfaction and loyalty. Total Quality Management Busines Excellent. 15 (6), 859-868.

Flamm, B.J. (2009). The impacts of environmental knowledge and attitudes on vehicle ownership and use. Transportation Research Part D: Transport and Environment. 14 (4), 272279.

Ghozali, I (2008). Generalized Structured Component Analysis (GSCA) Model Persamaan Struktural Berbasis Komponen. Semarang. Badan Penerbit Universitas Diponegoro.

Kong, W., Jarun, A., Sulong, R.S. \& Lily J. (2014). The influence of consumers' perception of green products on green purchase intention. International Journal of Asian Social Science. 4(8), 924-939.

Laroche M., Bergeron J., \& Babaro-Forleo G. (2001). Targeting consumers who are willing to pay more for environmentally friendly products. Journal of Consumer Marketing. 18 (6), 503-520.

Okada, E.M. \& Mais, E.L. (2010). Framing the green alternative for environmentally conscious consumers, sustainability accounting. Management and Policy Journal. 1 (2), 222-234.

Orth, U.R., Campana, D. \& Malkewitz, K. (2010). Formation of consumer price expectation based on package design: attractive and quality routes. Journal of Marketing Theory and Practice, 18(1), 23-40.

Pankaj, K.A. \& Vishal, K.L. (2014). Consumer adoption of green products and their role in resource management. Indian Journal of Commerce \& Management Studies. 5 (3), 22-28.

Patel, C.P. \& Chugan, P.K. (2015). The influence of consumer perception towards green advertising on green purchase intention. International Journal of Entrepreneurship \& Business Environment Perspectives. 4(3), 18651873.

Rahim, A. (2012). Green advertising and environmentally responsible consumer behavior: the level of awareness and perception of Malaysian youth. Asian Social Science. 8 (5), 46-54. 
Rex, E \& Baumman. H. (2007). Beyond ecolabels what green marketing can learn from conventional marketing. Journal of Cleaner Production. 15, 567576.

Rokka, J. \& L. Uusitalo, (2008). Preference For Green Packaging In Consumer Product Choices - Do Consumers Care? International Journal of Consumer Studies. 32(5), 516-525.

Rundh, B. (2009). Packaging design: Creating competitive advantage with product packaging. British Food Journal. 111 (9), 988-1002.

Ruwani, A., Retnaningsih, \& Simanjuntak, M. (2014). Nilai dan tipe konsumen rumah tangga dan kaitannya dengan perilaku pembelian produk makanan kemasan. Jurnal IImu Keluarga dan Konsumen. 7(1), 48-57.

Saxena, R.P. \& Khandelwal, P.K. (2012). Greening of industries for sustainable growth: An exploratory study on durable, non-durable and services industries. International Journal of Social Economics, 38(9), 551-586.
Schiffman, L. G. \& Kanuk, L. (2004). Consumer Behavior ( ${ }^{\text {th }} \quad$ ed.). Englewood Cliffs, NJ: Prentice-Hall.

Susila, B., Sumarwan, U. \& Kirbrandoko. (2014). Analisis kepuasan konsumen terhadap brand switching behavior minuman teh dalam kemasan. Jurnal IImu Keluarga dan Konsumen. 7(3): 193-201.

Tenenhaus, M. (2008). State of Art on PLS Path Modeling Throught The Avalaible Software. HEC France.

Verlegh, P. W., Steenkamp, J. B. E. \& Meulenberg, M. T. (2005). Country-oforigin effects in consumer processing of advertising claims. International Journal of Research in Marketing, 22. (2), 127139.

Wu, S. \& Chen, Y. (2014). The impact of green marketing and perceived innovation on purchase intention for green products. International Journal of Marketing Studies. 6(5), 81-100. doi:10.5539/ijms.v6n5p81 